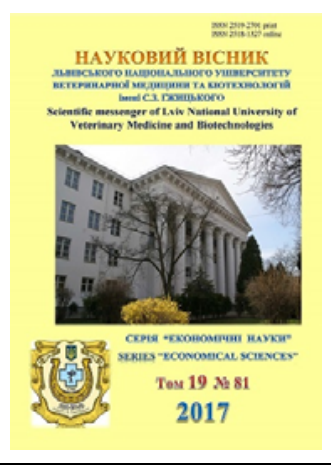

УДК 338.24: 334.012.23 (477.83)
Науковий вісник Львівського національного університету ветеринарної медицини та біотехнологій імені С.3. Гжицького

Scientific Messenger of Lviv National University of Veterinary Medicine and Biotechnologies

doi:10.15421/nvlvet8112

ISSN 2519-2701 print

ISSN 2518-1327 online

http://nvlvet.com.ua/

\title{
Ефективність виробництва аграрної продукції сільськогосподарськими підприємствами Львівщини
}

\author{
А.М. Шульський \\ pretty_62@ukr.net \\ Львівський національний університет ветеринарної медицини та біотехнологій імені С.З. Гжищького, \\ вул. Пекарська, 50, Львів, 79010, Україна
}

\begin{abstract}
В статті проведено дослідження щзодо ефективності виробництва аграрної продукції сільськогосподарськими підприємствами Львівської області. Загальна їх кількість представлена в таблиці 1. Аналіз рівня рентабельності виробництва ними окремих видів продукиї сільського господарства, що наведено в таблиці 2, дає підстави констатувати, що в рослинницьких галузях продукування продукиії є рентабельним за винятком виробництва картоплі у 2016 р. (рівень збитковості становив - 7,9\% і иукрового буряку в 2005 р. (рівень збитковості складав - 15,3\%). В тваринництві ситуація більш складніма - тут значна частина виробництва різних видів продукиї збиткова. Через низьку рентабельність припинили ведення вівчарства і козівництва. Узагальнено показники ефективності виробнищтва продукиії, які протягом 2010 р., 2015 p. $i$ 2016 р. були позитивними. Однак иі досягнення не слід розглядати з позичії розв'язання проблем ефективності, адже в загальних показниках часто не знаходять відображення конкретні негативні явища. Дані таблиці 2 є тому підтвердженням. 3 наведеного матеріалу можна констатувати, що в умовах сьогодення значної підтримки вимагає галузь тваринництва. При цьому значну роль у цій підтримиі повинна відігравати держава.

Ключові слова: ефективність, виробництво, рівень рентабельності, аграрна продукиія, сільськогосподарські підприємства, рослинництво, тваринництво.
\end{abstract}

\section{Efficiency of production of agrarian products by agricultural enterprises of Lviv region}

\author{
A.N. Shulskyy \\ pretty_62@ukr.net
}

Stepan Gzhytskyi National University of Veterinary Medicine and Biotechnologies Lviv, Pekarska Str., 50, Lviv, 79010, Ukraine

The article analyzes the efficiency of agricultural production by agrarian enterprises. To accomplish the tasks and on the basis of this achievement, the goal of the study was conducted in a certain logical sequence using statistical materials during 2005-2016. Thus, in particular, the beginning of the study was carried out in the presence of all agricultural enterprises in the Lviv region and in the context of their separate groups. At the same time, each separate group of enterprises, presented separately using the materials of the Commercial Code. Such methodological approaches have allowed to find out the essential common and distinctive features of each individual group. The analysis of the level of profitability of the main types of agricultural products produced by agricultural enterprises of Lviv region (Table 2) gives grounds to state that in the plant growing areas the production of the products is profitable for the exclusion of potato production in 2016 (the level of loss-making was 7.9\% and sugar beet in 2005 (the level of loss-making was $15.3 \%$ ). In the livestock sector, the situation is more complicated, with a large part of the various types of products being unprofitable, because of the low profitability they stopped keeping sheep and goats.

Table 3 shows the generalized performance indicators of production during 2010; 2015 and 2016 were positive. However, these achievements should not be considered from the standpoint of solving the problems of efficiency, because in general indicators are

Citation:

Shulskyy, A.N. (2017). Efficiency of production of agrarian products by agricultural enterprises of Lviv region. Scientific Messenger LNUVMB, 19(81), 74-78. 
often not reflected specific negative phenomena. The data in Table 2 is a confirmation. From the given material it is possible to state that in the present conditions considerable support is required by the livestock sector. At the same time, the state should play a significant role in this support. bandry.

Key words: efficiency, production, profitability level, agrarian products, agricultural enterprises, plant growing, animal hus-

\section{Вступ}

Виробництво аграрної продукції забезпечується різними видами господарських формувань, провідне місце серед яких займають сільськогосподарські підприємства. Ці господарські структури в умовах сучасності відіграють провідну роль. Такими вони будуть і на ближчу перспективу. Враховуючи ці обставини, суть постановки проблеми полягає в тому, щоб обгрунтувати цей позитивний напрям розвитку сільськогосподарських підприємств 3 використанням показників ефективного ведення господарської діяльності.

Аналіз останніх досліджень $і$ публікаџій. Ефективність ведення аграрного виробництва є одним із ключових напрямів результативного здійснення діяльності організаційно-господарськими структурами системи АПК. Цими проблемами займалися і займаються в умовах сучасності ціла плеяда відомих вченихаграрників, серед яких відзначимо: А.Г. Андрійчук, О.В. Березін, В.М. Жук, М.Й. Малік, Ю.О. Лупенко, В.Я. Месель-Веселяк, С.В. Мочерний, О.В. Олійник, O.P. Шпикуляк та інші (Mochernyi, 2002; Andriichuk, 2005; Oliinyk, 2010; Berezin and Plotnyk, 2012; MeselVeseliak, 2016; Malik and Shpykuliak, 2017; Korysko, 2017). Однак, незважаючи на значну кількість досліджень і публікацій одержаних результатів досліджень, в останні роки, проблему ефективності варто досліджувати й надалі. Адже аграрне виробництво, як i будь-яка сфера національного господарства, постійно розвивається і удосконалюється під впливом чинників внутрішнього і зовнішнього середовища. I ці зміни слід детально досліджувати, а одержані резуль- тати опубліковувати як у наукових, так і в інших виданнях.

Постановка завдання полягає у розробці конкретних підходів для досягнення поставленої мети. Ціль даної роботи - визначення і обгрунтування основних показників ефективності ведення аграрного виробництва сільськогосподарськими підприємствами, які в сучасних умовах є одними із провідних господарських формувань у системі АПК.

\section{Результати та їх обговорення}

Серед різних форм господарювання, що забезпечують виробництво аграрної продукції в Україні, помітне місце займають сільськогосподарські підприємства. Вони різноманітні щодо форм власності, організації ведення господарської діяльності та ін., а також різняться за кількістю їх в системі АПК (табл. 1). При цьому, варто зауважити, їх наявність постійно змінювалася протягом досліджуваних років під впливом умов внутрішнього та зовнішнього середовища. Дані таблиці 1. підтверджують сказане.

Враховуючи тему дослідження даної публікації, виникає об'єктивна необхідність щодо більшої конкретизації представленої інформації, що і нами буде зроблено нижче. Отож, з'ясуємо перш за все, як трактується поняття сільськогосподарське підприємство. В статистичних збірниках відзначається, що це: «суб'єкт господарювання», який має право юридичної особи, або відокремлений підрозділ юридичної особи, що здійснює систематичну виробничу діяльність у галузі сільського господарства. До складу сільськогосподарських підприємств включають також фермерські господарства (Andriichuk, 2005).

Таблиия 1 *

Кількість сільськогосподарських підприсмств Львівщини (станом на 1 листопада, одиниць)

\begin{tabular}{|l|c|c|c|c|c|c|}
\hline \multicolumn{1}{|c|}{ Форми господарств } & & & & \multicolumn{2}{|c|}{2016 p. «+», «-» до } \\
\cline { 5 - 8 } & 2005 p. & 2010 p. & 2015 p. & 2016 p. & 2005 p. & 2015 p. \\
\hline $\begin{array}{l}\text { Усього } \\
\text { у тому числі: }\end{array}$ & 1725 & 1490 & 1428 & 1209 & -516 & -219 \\
\hline господарські товариства & 304 & 250 & 224 & 251 & -53 & +27 \\
\hline приватні підприємства & 200 & 177 & 128 & 119 & -1 & -9 \\
\hline виробничі кооперативи & 12 & 13 & 16 & 31 & +19 & +15 \\
\hline фермерські господарства & 1161 & 1002 & 1044 & 788 & -373 & -256 \\
\hline державні підприємства & 23 & 10 & 6 & 7 & -16 & +1 \\
\hline $\begin{array}{l}\text { підприємства інших форм господа- } \\
\text { рювання }\end{array}$ & 25 & 38 & 10 & 13 & & -12 \\
\hline
\end{tabular}

Примітка: * тут і далі використано матеріали Статистичного збірника (Korysko, 2017)

Питання включення фермерських господарств до складу сільськогосподарських підприємств є дискусійним і відповідь $€$ неоднозначною. Не будемо вдаватися в наукову полеміку з цих проблем, лише відзначимо, що, на наше переконання, кожна форма господарювання в системі введення аграрного виробництва повинна зайняти свою характерну саме для неї відповідну нішу за наслідками господарювання, а не розчинятися у загальних показниках господарювання певної групи. Згідно з Законом України «Про фермерське господарство» відзначено, що фермерське господарство, зареєстроване як юридична особа, має статус сімейного фермерського господарства, за умови, що в його підприємницькій діяльності використовується праця членів такого господарства, якими є виключно члени однієї сім’ї відповідно до статті 3 Сімейного 
кодексу України. Слід відзначити, що фермерське господарство може здійснювати свою діяльність у статусах як юридичної особи, так і неюридичної особи (організовується на основі діяльності фізичної особи - підприємця і має статус сімейного фермерського господарства).

В склад сільськогосподарських підприємств, як показують матеріали таблиці 1, входять інші господарські формування, суть і зміст діяльності яких представимо із інформації, що міститься в Господарському кодексі. Отож:

- господарськими товариствами визначаються підприємства або інші суб'єкти господарювання, створені юридичними та/або громадянами шляхом об'єднання їх майна і участі в підприємницькій діяльності товариства 3 метою одержання прибутку (Berezin and Plotnyk, 2012);

- приватним підприємством визначається підприємство, що діє на основі приватної власності одного або кількох громадян, осіб без громадянства та його (їх праці) чи 3 використанням найманої праці. Приватним також є підприємство, що діє на основі приватної власності суб'єкта господарювання - юридичної особи (Berezin and Plotnyk, 2012);

- виробничим кооперативом визнається добровільне об'єднання громадян на засадах членства 3 метою спільної виробничої або іншої господарської діяльності, що базується на їх особистій трудовій участі та об'єднанню внесків, участі в управлінні підприємством та розподілу доходу між учасниками кооперативу відповідно до їх участі у його діяльності (Berezin and Plotnyk, 2012);

- державне унітарне підприємство утворюється компетентними органами державної влади в розпорядчому порядку на базі відокремленої частини державної власності, як правило, без поділу їі на частини, i входять до сфери його управління (Berezin and Plotnyk, 2012).

Різні господарські формування відрізняються між собою в основному формами власності, їх організації та підходами до здійснення ними виробничої діяльності і управління. Протягом досліджуваного періоду кількість сільськогосподарських підприємств не $є$ стабільною величиною. При цьому спостерігаються тенденції до їх зменшення (табл. 1). Це зменшення не означає зниження можливостей виробничої діяльності. Тут фактично відбулись процеси кількісного зменшення господарюючих одиниць шляхом їх укрупнення, що супроводжувалося збільшенням земельних угідь. Так, скажімо, кількість фермерських господарств у 2016 р. зменшилась до 788 одиниць проти 1002 одиниць у 2005 р., однак площі сільськогосподарських угідь збільшились у 2016 р. до 55437 гектарів, у тому числі ріллі до 51036 га, тоді як у 2005 р. ці показники відповідно складали: 54113 і 47421 га, а це становило рівня 2016 відповідно: 97,6 і 92,9\%.

Отож, аналізуючи кількісне зменшення чи збільшення тих чи тих господарських одиниць, необхідно одночасно брати до уваги зміни у них земельних угідь, наявність яких і характеризує потенційні можливості підвищення їх виробничої діяльності. Через ці обста- вини доцільно було б статистичним органам одночасно із кількістю сільськогосподарських підприємств подавати цифрову інформацію про наявність земельних угідь у них.

Крім сказаного вище, варто проаналізувати деякі цифрові показники. Насамперед це наявність виробничих кооперативів. Хоча у 2016 р. наявність цих структур зросла з 12 одиниць у 2005 р. до 31 одиниць у 2016 р., однак це не означає, що досягнуто значних зрушень у розвитку кооперативного руху у Львівській області. Саме тому в сучасних умовах слід приділити значну увагу розвитку кооперації в аграрному виробництві. При цьому важливо інтенсивно розвивати не тільки виробничу, але і обслуговуючу кооперацію. Щодо державних підприємств, то їх кількість зменшилась до критичної межі. В останні роки (2015 р. і 2016 р.) їх зменшилось до 6-7 одиниць на Львівщині, тоді як у 2005 р. їх нараховувалось 23 підприємств. Ми вважаємо, що держава повинна займати більш помітне і вагоме місце в аграрному виробництві, ніж вона займає зараз. Ці господарства повинні бути високомеханізовані, характеризуватися високим рівнем організації технологічних і управлінських процесів i, що головне, високою ефективністю виробництва продукції. Все це в комплексі дозволило б їм бути зразком та еталоном для здійснення аграрної діяльності іншими господарськими формуваннями.

Підсумовуючи вищесказане, відзначимо, що важливими показниками розвитку як сільськогосподарського, так і інших галузей національного господарства $\epsilon$ ефективність їх ведення. В енциклопедичних виданнях щодо аграрної сфери стверджується: «Ефективність сільського господарства - результативність господарської і фінансової діяльності суб'єктів господарювання, здатних забезпечувати високі показники продуктивності праці зниження фондовіддачі та собівартості, зростання рентабельності, врожайності сільськогосподарських культур та ін.» (Mochernyi, 2000). Отож, ефективність виробництва сприяє раціональному і результативному веденню виробничої діяльності і $є$ наслідком іiі ведення. Ефективність, як відомо, характеризується цілим комплексом різноманітних показників, важливим серед яких є рівень рентабельності. Щодо сільського господарства. Цей показник трактується, як показник ефективності виробництва різних видів сільськогосподарської продукції (зерна, овочів, м'яса тощо), окремих галузей (рослинництва, тваринництва та ін.)господарств і всього сільського господарства (Mochernyi, 2000). Для конкретизації результатів дослідження рівня рентабельності основних видів аграрної продукції, з'ясуємо, що цей показник трактується як: «відношення прибутку від реалізації продукції до повних витрат, собівартості ії виробництва та обігу» (Mochernyi, 2000). Обчислені рівні рентабельності основних видів аграрної продукції представлені у таблиці 2.

Наведені показники рівня рентабельності основних видів аграрної продукції у сільськогосподарських підприємствах Львівської області характеризуються за досліджуваний період 2005-2016 рр. різними величинами. Деякі показники 3 деяких видів продукції відзначаються їх строкатістю, що є причиною не ви- 
явлення чітких тенденцій і закономірностей їх змін. Так, скажімо, культури плодові та ягідні характеризувалися у 2005 р. і 2010 р. Збитковістю $(-49,4$ і $-60,5 \%)$, а у 2015 р. рівень їх рентабельності сягнув позначки $213.3 \%$, а в наступному році знизився до 10,1\%. Коли більш деталізовано проаналізувати рівень рентабельності продукції за 2016 р., то можна констатувати, що серед продукції рослинництва нерентабельною була лише картопля, а серед тваринницької продукції - велика рогата худоба і птиця на м'ясо.

Щодо позитивних зрушень, то варто відмітити, що за досліджуваний період відбулось незначне підвищення рівня рентабельності вирощування цукрових фабричних буряків. В цій галузі утвердилася тенденція до зростання їх рівня рентабельності. Досить також відзначити, що буряківництво за колишньої системи було провідною галуззю сільського господарства Львівщини. Такою вона стає в умовах сучасності і такою, безумовно, вона повинна бути і в майбутньому. Серед продукції тваринного походження значною стабільністю рентабельного ведення відзначається молочне скотарство (рівень рентабельності виробництва молока зріс із 8,0\% у 2005 р. до $21,2 \%$ у 2016 р.), свинарство (тут рівень рентабельності свинини зріс від $10,8 \%$ у 2010 р. до $50,4 \%$ у 2015 р. і $33,9 \%$ у 2016 р.). Позитивними зрушеннями характеризується виробництво курячих яєць. Вся інша продукція тваринництва відзначається в більшій мірі нерентабельним веденням, ніж рентабельним. Отож на ці галузі повинні бути сконцентровані зусилля щодо виведення ïx із стану збитковості. Помітну роль у цих процесах повинна відігравати держава, надаючи певні суми фінансової допомоги.

Рівень рентабельності окремих видів аграрної продукції відображається у ії сукупності забезпечення рентабельного ведення окремих галузей, чи взагалі визначає ефективність виробництва в цілому. Враховуючи ці аспекти, в таблиці 3 наведена цифрова інформація щодо прибутковості (збитковості) як окремих аграрних галузей, так і господарської діяльності в цілому.

Табличя 2

Рівень рентабельності основних видів аграрної продукції у сільськогосподарських підприємствах Львівщини, \%

\begin{tabular}{|l|c|c|c|c|c|c|}
\hline \multicolumn{1}{|c|}{ Види продукції } & \multirow{2}{*}{$2005 \mathrm{p}}$. & \multirow{2}{*}{$2010 \mathrm{p}}$. & \multirow{2}{*}{$2015 \mathrm{p}}$. & \multirow{2}{*}{$2016 \mathrm{p}}$. & \multicolumn{2}{|c|}{$2016 \mathrm{p}$. «+», «-» до } \\
\cline { 4 - 7 } & & 4,5 & 25,3 & 11,3 & $+8,9$ & $-14,0$ \\
\hline Культури зернові та зернобобові & 2,4 & 4,5 . & 2015 . \\
\hline Буряк цукровий фабричний & $-15,3$ & 56,0 & 44,0 & 61,4 & $+59,3$ & $+17,4$ \\
\hline Культури овочеві відкритого грунту & 39,9 & 95,9 & 184,9 & 16,1 & $-20,8$ & $+165,8$ \\
\hline Картопля & 4,8 & 41,2 & 0,9 & $-7,9$ & $-12,7$ & $-8,8$ \\
\hline Культури плодові та ягідні & $-49,4$ & $-60,5$ & 213,3 & 10,1 & $+59,5$ & $-203,2$ \\
\hline Молоко & 8,0 & 15,0 & 15,0 & 21,2 & $+13,2$ & $-6,2$ \\
\hline Велика рогата худоба на м’ясо & $-34,9$ & $-36,4$ & $-15,5$ & $-18,1$ & $+16,8$ & $-2,6$ \\
\hline Свині на м'ясо & 21,5 & 10,8 & 50,4 & 33,9 & $+12,4$ & $-16,5$ \\
\hline Вівці і козине м'ясо & $-46,9$ & $-45,6$ & - & - & - & - \\
\hline Птиця на м’ясо & 13,1 & 4,0 & $-5,7$ & $-1,2$ & $-14,3$ & $+4,5$ \\
\hline Яйця курячі & 18,7 & $-5,5$ & 21,6 & 24,1 & $+5,4$ & $+2,5$ \\
\hline
\end{tabular}

Ефективність виробництва аграрної продукції у сільськогосподарських підприсмствах Львівщини

\begin{tabular}{|l|c|c|c|c|c|c|}
\hline \multicolumn{1}{|c|}{ Показники } & 2005 p. & 2010 p. & 2015 p. & 2016 p. & \multicolumn{2}{|c|}{2016 p. «+», «-» до } \\
\cline { 4 - 8 } & & 2005 p. & 2015 p. \\
\hline $\begin{array}{l}\text { Прибуток, збиток (-) від реалізації } \\
\text { аграрної продукції, млн грн }\end{array}$ & 22,0 & 333,7 & 1297,3 & 987,2 & 4,5 раза & 76,1 \\
\hline $\begin{array}{l}\text { у тому числі: } \\
\text { продукція рослинництва }\end{array}$ & 27,0 & 331,1 & 1109,7 & 825,5 & 76,1 & 74,4 \\
\hline продукція тваринництва & $-4,5$ & 2,6 & 187,6 & 161,7 & 166,2 & 86,2 \\
\hline $\begin{array}{l}\text { Рівень рентабельності виробництва } \\
\text { аграрної продукції, \% }\end{array}$ & 7,9 & 27,6 & 28,3 & 21,9 & $+14,0$ & $-6,4$ \\
\hline $\begin{array}{l}\text { у тому числі: } \\
\text { продукція рослинництва }\end{array}$ & 17,2 & 39,6 & 29,4 & 23,1 & $+5,9$ & 6,3 \\
\hline продукція тваринництва & $-3,6$ & 0,7 & 22,9 & 17,4 & $+21,0$ & $-5,5$ \\
\hline
\end{tabular}

Як показують дані таблиці 3, протягом досліджуваних років (2005 р., 2015 р. і 2016 р.) аграрна галузь у сільськогосподарських підприємствах Львівщини були прибутковою, за винятком продукції тваринництва у 2005 р., сума збитку у цьому році становила 4,5 млн грн. Такими самими тенденціями характеризується рівень рентабельності в загальному виразі і в галузевому розрізі. Тут все вписується у відомий принцип: «Збільшення прибутковості сприяє зростанню рівня рентабельності і навпаки».

\section{Висновки}

На основі проведеного дослідження можна констатувати про наступне:

- до складу сільськогосподарських підприємств входять різноманітні за своєю структурною і організаційною будовою господарські формування. Вони також різняться формами власності, наявністю земельних угідь та їх використанням, технологією виробництва, здійснення організаційних процесів тощо. 
Саме найбільш важлива складова це земельні угіддя. I саме тому статистичним органам разом із кількістю господарств (табл. 1) слід наводити інформацію про наявність в них земельних угідь;

- визначення рівнів рентабельності аграрної продукції (табл. 2) вказують, що не всі їх види є рентабельними. Через ці обставини вважаємо за необхідне розробки конкретних заходів щодо підтримки виробництва тих видів продукції сільського господарства, які $\epsilon$ нерентабельними. При цьому особлива роль в цих процесах повинна належати державі, яка має виступати як стабілізуюча складова аграрних галузей. Дані таблиці 3 діалектично зв'язані із показниками таблиці 2 і доповнюють одні одних.

Узагальнюючи вищесказане, відзначимо, що хоча в останні роки сільськогосподарські підприємства Львівщини досягли деякого підвищення економічної ефективності аграрної продукції, однак вони не в повній мірі використали свій потенціал для зростання ефективного ведення як окремих аграрних галузей, так і господарської діяльності в цілому. Однак ця тема окремих нових пошукових досліджень i, отже, підготовки нових публікацій.

\section{Бібліографічні посилання}

Andriichuk, V.H. (2005). Efektyvnist diialnosti ahrarnykh pidpryiemstv: teoriia, metodyka, analiz: Monohraf. K.: KNEU (in Ukrainian).

Berezin, O.V., Plotnyk, O.D. (2012). Ekonomichnyi potentsial ahrarnykh pidpryiemstv: mekhanizmy formuvannia ta rozvytku: Monohrafiia. Poltava: Inter Hrafika (in Ukrainian).

Hospodarskyi kodeks Ukrainy (2014). Chynne zakonodavstvo Ukrainy zi zminamy ta dopovnenniamy stanom na 3 veresnia 2014.: (vidpovidaie ofitsiinomu tekstovi). K.: Tsentr uchbovoi literatury (in Ukrainian).

Mochernyi, S.V. (2000). Ekonomichna entsyklopediia: U trokh tomakh. K.: Vydavnychyi tsentr «Akademiia» (in Ukrainian).

Mochernyi, S.V. (2002). Ekonomichna entsyklopediia: U trokh tomakh. T.3. K.: Vydavnychyi tsentr «Akademiia» (in Ukrainian).

Malik, M.I., Shpykuliak, O.R. (2017). Rozvytok ahrarnoho pidpryiemstva $\mathrm{V}$ umovakh instytutsionalnykh transformatsii. Ekonomika APK. 2, 5-16 (in Ukrainian).

Mesel-Veseliak, V.Ia. (2016). Efektyvnist hospodariuvannia novostvorenykh silskohospodarskykh pidpryiemstv rynkovoho spriamuvannia. Ekonomika APK. 12, 21-33 (in Ukrainian).

Oliinyk, O.V. (2010). Stalist rozvytku hospodarstv riznykh katehorii $\mathrm{v}$ ahrarnomu sektori Ukrainy. Orhanizatsiino-ekonomichni transformatsii v ahrarnomu vyrobnytstvi. Zbirnyk materialiv Dvanadtsiatykh richnykh zboriv Vseukrainskoho konhr. Vchen. ekonomistiv - ahrarnykiv, Kyiv. K.: NNTs «IAE», 124-127 (in Ukrainian).

Korysko, H. (2017). Silske hospodarstvo Lvivskoi oblasti. Statystychnyi zbirnyk. Lviv (in Ukrainian).

Hadzalo, Ia.M., Bashchenko, M.I., Zhuk, V.M., Lupenko, Iu.O. (2016). Stratehiia rozvytku silskohospodarskoho vyrobnytstva v Ukraini na period do 2025 roku. K.: Ahrarna nauka (in Ukrainian). 